Leadership: Jurnal mahasiswa manajemen Pendidikan Islam

ISSN (P): 2721-7108, ISSN (E): 2715-0399

DOI : http://dx.doi.org/10.32478/leadership. v3i1.876

Article Type : Original Research Article

\title{
Implementasi Education Management Information System ( EMIS ) Dalam Mengelolah Data Lembaga Di Madrasah Tsanawiyah Darussa'adah Gubugklakah Kecamatan Poncokusumo Kabupaten Malang
}

\author{
Husnil Mubarok \\ STAI Ma'had Aly Al-Hikam Malang, Indonesia
}

Corresponding author: Email: husnilmubarok@gmail.com

Submission Track:

Submisson : :03-01-2022

Accept Submission : 04-01-2022

Avaliable Online : 04-01-2022

Copyright @ 2022 Author

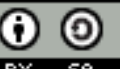

This work is licensed under a Creative Commons Attribution-ShareAlike 4.0

\begin{abstract}
:
The rapid development and advancement of technology has made significant changes to the condition of society, both in terms of policy, communication, biocracy, or at any existing institutions, without exception educational institutions. Educational institutions are institutions that are directly affected by developments in the times and technology, so that educational institutions are required to be able to keep up with any changes and developments in the vicinity, especially technological developments. The Education Management Information System or known as EMIS is a form of technological development, which is useful in providing real data for educational institutions as a support in managing new useful data and information for its users using computers and internet networks. EMIS is a combination of human resources and other computer-based resources that produces cumulative data storage, recovery, communication, and use for the purpose of effective and efficient school management operations
\end{abstract}

Keywords : Management Information System, EMIS, Implemtation,

Abstrak :

Pesatnya perkembangan dan kemajuan teknologi menjadikan perubahan yang signifikan terhadap keadaan masyarakat, baik dalam hal Kebijakan, komunikasi, biokrasi, ataupun pada setiap intansi-intansi yang ada, tanpa terkecuali 
Leadership: Jurnal mahasiswa manajemen pendidikan Islam

ISSN (P): 2721-7108, ISSN (E): 2715-0399

Vol. 03 No. 01 bulan Desember 2021

lembaga pendidikan. Lembaga pendidikan merupakan intansi yang terkena imbas langsung terkait perkembangan zaman dan teknologi, sehingga lembaga pendidikan ditutuntut mampu mengikuti setiap perubahan dan perkembangan sekitar khususnya perkembangan teknologi. Education Management Information System atau yang terkenal dengan sebutan EMIS merupakan wujud dari perkembangan teknologi, yang berguna dalam memberikan data rill lembaga pendidikan sebagai pendukung dalam mengelolah berbagai data dan informasi baru yang bermanfaat bagi para penggunanya dengan menggunakan komputer dan jaringan internet. EMIS merupkan perpaduan antara sumber daya manusia dan sumber daya lainnya yang berlandaskan komputer yang menghasilkan kumulan penyimpanan, perolehan kembali, komunikasi, dan penggunaan data untuk tujuan operasi manajemen sekolah yang efektif dan efisien.

Keywords : Sistem Informasi Manajemen, EMIS, Implementasi

\section{PENDAHULUAN}

Pada masa sekarang kita berada diera digital, era dimana komunikasi dan juga informasi hampir keseluruhannya menggunakan basis teknologi baik komputer maupun handphone. Bersamaan dengan perkembangan digital yang bergitu pesat, informasi menjadi suatu sumber daya yang begitu penting sebagai mana yang kita tahu bahwa hampir seluruh waktu telah dihabiskan untuk mecari, bahkan menyimpan dan bertukar informasi, lebih-lebih dalam sebuah oeganisasi khususnya lembaga pendidikan.

Sejalan sengan informasi yang kini menjadi sumber daya yang sangat penting bagi sebuah lembaga pendidikan, maka tuntutan utama bagi lembaga pendidikan tersebut adalah menjadikan pengelolan informasi menjadi lebih efektif sehingga lembaga tersebut dapat mencapai tujuannya. Inilah mengapa lembaga pendidikan harus mampu mengkuti setiap perkembangan dengan menumbuhkan kesadaran terhadap beberapa pihak khususnya stake holder lembaga bahwa, perkembangan dan trobosan informasi akan terus berkembang sehingga hal ini menjadikan sebuah tantangan bagi setiap lembaga pendidikan agar mampu memanfaatkan perkembanga tersebut. ${ }^{1}$

Perkembangan teknologi dan informasi, memiliki peran penting dalam menunjang tercapainya tujuan pendidikan, dikarenakan teknologi dan informasi menjadi basis utama dalam pengumpulan data dan pemberian informasi terkait lembaga pendidikan. Jika sebuah lembaga pendidikan tidak mendapatkan dukungan data infomasi yang berkualitas, maka dapat dipastikan akan mengalami banyak hambatan dan kesulitan-kesulitan lebih-lebih dalam proses yang berhubungan langsung dengan pengambilan keputusan dan strategi. Hal ini akan berdampak pada kegagalan dalam mencapai tujuan pendidikan. ${ }^{2}$

Implementasi sistem informasi manajemen yang ada pada lembaga pendidikan diantarnya meliputi pengolahan data lembaga seperti data peserta didik, data guru dan

\footnotetext{
${ }^{1}$ Selvia Arfan, Muhammad Yumni, Muh Yusuf T," Penerapan Sistem Informasi Manajemen dalam Pengeolahan Data Peserta Didik Di MI Nasrul Haq, ”Jurnal Idaarah,Vol.III,No.2, (Desember 2019),hlm. 289.

${ }^{2}$ Dodi Irawan Syarip, dan Rosidin, System Manajemen Data dan Informasi Pendidikan di Lingkungan Diretorat Jenderal Kelembagaan Agama Islam(Jakarta : Departemen Agama RI,2003),hlm.1
} 
tenaga kependidikan, data sarpras, kurikulum, dan juga terkait profil sekolah yang diolah menjadi sebuah komponen pendukung pelaksanaan penyelengaraan pendidikan. Sehingga, secara tidak langsung lembaga pendidikan akan memperoleh beberapa manfaat diantaranya :

1. Tersedianya sistem pengelolaan data dan informasi pendidikan,

2. Terintgrasinya data dan informasi lembaga pendidikan untuk mendukung proses pengambilan keputusan,

3. Tersedianya data dan informasi pendidikan yang lengkap bagi seluruh stakeholders yang berkepentingan dalam bidang pendidikan. ${ }^{3}$

EMIS dapat dikatakan sebagai salah satu wadah sebagai pendukung terkait informasi dan data seputar lembaga pendidikan terkait. EMIS akan mengatur dan mengelolah data sesuai dengan kebutuhan lembaga pendidikan, misalnya secara umum penyediaan data tentang jumlah kapasitas atau daya tampung sekolah dari mulai tingkat dasar seperti perencanaan jumlah kelas, jumlah peserta didik, sumber daya manusia untuk pendidik dan tenaga kependidikan dan sebagainya. Sehingga EMIS dapat dijadikan data rill tentang lembaga pendidikan. Oleh karena itu EMIS harus betul-betul dipahami fungsi dan kegunaannya, terlebih bagi Operator atau tenaga kependidikan yang bertugas mengoprasikan sistem tersebut.

Senyatanya, EMIS sebagai penyedia data riil lembaga pendidikan yang ada banyak dari lembaga pendidikan yang belum $100 \%$ riil dalam mengoprasikan EMIS hal ini dikarenakan masih banyak kendala baik dari sistem itu sendiri dan juga dari pengumpulan data yang ada pada lembaga pendidikan terkait seperti, kurang lengkapnya informasi data mengenai siswa, kurang rillnya data terkait keadaan lembaga tersebut, atapun kendala serfer pusat EMIS yang juga sering mengalamai trobel.

Melalui uraian latar belakang diatas, penulis merasa tertarik untuk mengetahui dan memahami sejauh mana EMIS dilembaga pendidikan MTs Darussa'adah Gubugklakah Kecamatan Poncokusumo yang juga mengalami kendala terkait dengan keabsahan data yang ada pada EMIS, sehingga penulis menarik judul tentang Implementasi Education Management Information System (EMIS) Dalam Mengelolah Data Lembaga di MTs Darussa'adah Gubugklakah Kecamatan Poncokusumo

\section{Sistem Informasi Manajemen Lembaga Pendidikan}

Sistem Informasi Manajemen atau SIM merupakan suatu system yang dirancang dengan tujuan menyediakan dan mengambil sebuah keputusan dalam setiap kegiatan manajemen. Penjelasan ini memberikan sebuah pemahaman bahwa SIM diartikan sebagai alat atau sarana pelayanan informasi, kinerja, dan efektifitas dalam perencanaan, pengorganisasian, penggerakkan, serta pengawasan yang terangkai dalam sebuah jaringan yang terhubung antara satu dengan yang lainnya dalam mencapai sebuah tujuan dari lembaga pendidikan. ${ }^{4}$

Beberapa pendapat terkait SIM pada dasarnya memiliki kesamaan pengertian, sebagaimana pendapat Suryadi Prawirosentono dalam bukunya mengartikan SIM sebagai

\footnotetext{
${ }^{3}$ Selvia Arfan, Muhammad Yumni, Muh Yusuf T," Penerapan Sistem Informasi Manajemen dalam Pengeolahan Data Peserta Didik Di MI Nasrul Haq, ”Jurnal Idaarah,Vol.III,No.2, (Desember 2019),hlm. 290.

4 Rasdiana Sina,Fatmawati,Abdul Mahsyar,"Penerapan Education Management Information System(EMIS) Di Lembaga Pendidikan Keagamaan dan Pondok Pesantren Pada Kantor Kementrian Agama Kota Makassar, ’JPPM,Vol.1,(Mei 2020),hlm. 39.
} 
infrastruktur yang didalamnya memfasilitasi pihak-pihak manajenen jika memerlukan informasi untuk pengambilan keputusan dalam sebuah organisasi dengan tujuan memenangkan pesaing melalui produk-produk yang sesuai dengan keinginan konsumen. ${ }^{5}$ Guna membentuk SIM yang handal tentu dibutuhkan system yang mampu menampung, mengolah data yang menghasilkan informasi dan data yang akurat. Sebab, tanpa adanya SIM yang handal maka akan sulit mewujudkan terbentuknya sebuah organisasi yang handal lebihlebih lembaga pendidikan. Dikarenakan dalam lembaga pendidikan SIM menolong dalam mengintregasikan data-data, mempercepat layanan, meningkatkan kualitas informasi, mendorong terciptanya berbagai layanan-layanan baru, mengoptimalisasikan berbagai pekerjaan khususnya yang berhubungan dengan data,menyederhanakan proses registrasi, keuangan, dan lain sebagainya. ${ }^{6}$

Oleh karena itu, untuk mewujudkan berbagai tujuan diatas, salah satu yang diterapkan pada setiap lembaga pendidikan adalah EMIS, yang merupakan wujud dalam pengembangan SIM yang berguna untuk mengintregasikan semua informasi terkait keadaan dan layanan pendidikan.

\section{Education Management Information System (EMIS)}

Education Manaement Information System atau EMIS merupakan sebuah metode dalam manajemen lebaga khususnya pendidikan yang menyediakan informasi yang akurat dan tepat. EMIS digunakan untuk mengatur data, dan informasi terkait pendidikan secara luas yang dapat dibaca, diproses, diambil kembali, dianalisis, dan dijadikan data rujukan lembaga. Diataranya keadaan lembaga pendidikan, input dan output siswa, fasilitas yang dimiliki, jumlah dan keadaan pendidik dan tenaga kependidikan, mutasi masuk dan mutasi keluar siswa.

Penggunaan EMIS dalam lembaga pendidikan secara tidak langsung memiliki beberapa tujuan diantaranya :

1. Menyediakan data dan informasi yang dibutuhkan dalam perumusan kebijakan, perencanaan, penyelenggaraan pendidikan, pengembangan objek, penyusunan anggaran, dan pengambilan keputusan.

2. Menyediakan dan mendukung pimpinan dengan data terbaru yang diperlukan untuk membuat perencanaan dan pengambilan keputusan skala kecil atau besar yang lebih efektif dan efisien.

3. Membantu percepatan otonomi daerah dan menyajikan data secara regional ( propinsi/kabupaten/kota) sehingga daerah dapat dengan baik menyusun rencana pembinaan dan penyelenggaraan pendidikan dengan mempertimbangkan aspek kesetaraan, kualitas, efifiensi, dan efektifitas.

4. Memperkuat kemampuan Kanwil ( propinsi ) dan Kementrian Agama (kabupaten/kota ) dalam memenuhi permintaan data dan informasi dari pejabat yang lebih tinggi.

5. Menilai pelaksanaan dan pencapaian tujuan pendidikan dimadrasah yang ilihat dari aspek kesetaraan, kualitas, efifiensi, dan efektifitas.

6. Memperkuat kemampuan untuk mengatur dan mengawasi alur informasi antar instansi

5 Faudi Aziz, "Pengambilan Kebijakan Berbasis Education Manajenen Inforation System (EMIS)",Jurnal Pendidikan Islam,Vol III,(Juni 2014),hlm. 138.

6 Faudi Aziz, "Pengambilan Kebijakan ................." hlm. 139 
yang saling berhubungan satu dengan yang lainnya.

7. Memadukan seluruh informasi yang berhubungan dengan manajemen kegiatan pendidikan dan menyajikan secara ringkas data-data yang dikelolah.

8. Memperbaiki kapasitas pengolahan, penyimpanan, dan analisis data dalam menyediakan informasi yang terpercaya dan tepat waktu.

9. Mengkoordinasikan proses pengumpulan, penyimpanan, pengolahan, analisis, dan penyebaran data dalam menyediakan informasi yang terpercaya.

10. Memudahkan dan meningkatkan penggunaan informasi yang sesuai agar perencanaan, pelaksanaan, dan manajemen pendidikan lebih efektif dan efisien.

11. Menyederhanakan alur informasi dalam pengambilan keputusan dengan menghapus proses duplikasi dan perbedaan pengisian informasi.

12. Mengaitkan berbagai system informasi yang ada.

13. Memadukan berbagai sumber informasi kuantitatif suatu system.

14. Memperbaiki proses pengumpulan, penyebaran, dan penggunaan informasi manajemen pendidikan dalam menanggapi perubahan kebutuhan informasi. ${ }^{7}$

\section{METODE PENELITIAN}

Peneliti dalam meneliti "Implementasi Education Management Information System (EMIS) Dalam Mengelolah Data Lembaga di Madrasah Tsanawiyah Darussa'adah Gubugklakah Kecamatan Poncokusumo" yaitu menggunakan teknik penelitian lapangan (fied research), yaitu penelitian yang berusaha mendeskripsikan pemecahan masalah yang ada berdasarkan data-data yang terjadi pada masa sekarang.

Penelitian lapangan (fied research) yang digunakan menuntut kehadiran peneliti di lokasi penelitian. Hal ini dikarenakan peneliti merupakan instrument utama atau kunci. Lokasi yang digunakan dalam objek penelitan ini dalah MTs Darussa'adah Gubugklakah yang beralamat di Jalan Raya Gubugklakah Kecamatan Poncokusumo kabupaten Malang.

\section{Teknik Pengumpulan Data}

peneliti menggunakan beberapa metode dalam pengumpulan data yang digunakan untuk mendukung hasil penelitian, diantaranya :

a. Wawancara

Wawancara dilakukan kepada subjek penelitian (Kepala Madrasa dan Operator Emis) dengan pedoman yang telah dibuat yang bertujuan untuk mengungkapkan permasalahan-permasahan dalam penerapan EMIS di lembaga terkait.

b. Observasi

Digunakan sebagai pengumpulan data dengan melakukan observasi pada lembaga pendidikan MTs Darussa'adah Kecamatan Poncokusumo yang dilihat dari pelaku atau operator, proses kerja, dan implementasi yang dilakukan terhadap lembaga terkait.

c. Dokumentasi

Rasdiana Sina,Fatmawati,Abdul Mahsyar,"Penerapan Education Management Information System(EMIS) Di Lembaga Pendidikan Keagamaan dan Pondok Pesantren Pada Kantor Kementrian Agama Kota Makassar, ”JPPM,Vol.1,(Mei 2020),hlm. 40. 
Leadership: Jurnal mahasiswa manajemen pendidikan Islam

ISSN (P): 2721-7108, ISSN (E): 2715-0399

Vol. 03 No. 01 bulan Desember 2021

Selain menggunakan metode wawancara dan observasi, dilakukan juga dokumentasi sebagai penguat hasil penelitian dilembaga terkait.

Teknik Analisis Data

Penelitian yang dilakukan peneliti adalah penelitian deskriptif dengan lebih banyak bersifat uraian dari hasil wawancara dan studi dokumentasi. Data yang diperoleh, akan dianalisis secra kualitatif serta diuraikan kedalam bentuk deskripsi.

\section{PEMBAHASAN}

\section{Implementasi Education Management Information System Dalam Mengelolah Data Lembaga di Madrasah Tsanawiyah Darussaadah Kecamatan Poncokusumo}

Pengelolaan data lembaga di Mts Darussa'adah kecamatan Poncokusumo dilakukan dengan menggunakan aplikasi EMIS berbasi online. Emis merupakan aplikasi yang dikembangkan oleh Kementrian Agama dengan tujuan untuk memudahkan pengolahan data madrasah, pondok pesantren, dan pendidikan agama lainnya. EMIS Online sendiri adalah aplikasi berbasis web sehingga dalam mengaksesnya dibutuhkan software seperti Mozilla Firefox, Google Chroom, dan sebagainya.

Emis adalah system yang menggunakan perpaduan antara sumber daya manusia dan teknologi digital yang dapat memlilih, menyimpan, mengolah, mengambil keputusan dan penarikan data. Untuk dapat menjalankan aplikasi tersebut maka madrasah harus memiliki akun terlebih dahulu. Hal ini sebagaimana yang disampaikan oleh operator MTs Darussa'adah bahwa : 8

"Agar madrasah dapat mengakses EMIS dan terdaftar pada EMIS, madrasah terlebih dahulu mendaftarkan akun, berupa email yang didaftrkan pada EMIS SDM. Setelah akun di approve dan aktif, maka madrasah bisa login dengan email yang telah didaftarkan di tahap awal dengan login ke situs http://emispendis.kemenag.go.id/emis madrasah/ dengan menggunaka user name dan password sebagai mana yang didaftarkan. Dikarenakan EMIS merupakan aplikasi online maka compute harus terhubung ke internet."

EMIS adalah sebuah aplikasi pendaataan lembaga yang didalamnya terdapat beberapa menu bagian diantaranya :

a. Halaman Utama atau Menu Dashboard yang mana menampilkan gambaran secaraglobal terkait isi data dalam EMIS

b. Menu Keterlembagaan, merupakan menu yang didalamnya meliputi profil lembaga, rekap guru dan tenaga kepenididikan, rekap siswa, proses kegiatan belajar mengajar, keuangan dan bantuan lembaga, menu sarana dan prasarana

c. Menu Kesiswaan, didalamnya meliputi siswa aktif, ringkasan jumlah siswa perrombel, lulusan siswa, mutasi masuk dan mutasi keluar, data alumni, siswa non aktif, dan siswa ganda

d. Menu GTK atau guru dan tenaga kependidikan, merupakan menu yang didalamnya meliput tentang jumlah guru dan tenaga kependidikan secara mendetail

\footnotetext{
${ }^{8}$ Opertor MTs Darussa'adah, Wawancara
} 
e. Template, merupakan fasilitas yang memudahkan bagi para operator untuk mengiput data melalui template xcell yang kemudian di Uplaod kedalam halaman emis

f. Konfirmasi, merupakan menu konfirmasi terkait kelembagaan, sarpras, siswa,dan PTK ketika data emis dinyatakan sudah sesuai dengan keadaan lembaga

g. Berita Acara, menu baru yang digunakan untuk mengunduh berita acara terkait proses penguploadan seluruh data EMIS

h. Logout atau menu keluar aplikasi

Sebagaimana dengan aplikasi-aplikasi pada umumnya, tentu EMIS memiliki banyak kendala, hal ini sebagaimana yang disampaikan oleh Operator MTs Darussa'adah ketika diwawancarai terkait kendala atau kesulitan dalam mengoprasikan EMIS, bahwa : ${ }^{9}$

"Kendala yang paling sering dialami oleh hampir semua operator lembaga adalah masalah server EMIS pusat yang sering trobel, hal ini tentu menyulitkan bagi kami, apalagi ketika sudah dikerar oleh dedline terakhir. Kemungkinan masalah ini terjadi karena server EMIS pusat yang mungkin kurang mumpuni sehingga, ketika banyak lembaga yang mengakses EMIS, maka akan blank. Seringnya server eror membuat kami para operator emis harus pintar-pintar memilih waktu penginputan data pada jam-jam yang sekiranya sedikit yang mengakses, seperti jam 12 malam atau bahkan jam 3 pagi."

Sulitnya akses sebagaimana yang disampaikan oleh operator EMIS, lebih-lebih saat dikerjakan pada jam-jam sibuk sangat dikeluhkan oleh hampir seluruh operator madrasah, sehingga penginputan data lebih sering dilakukan pada jam-jam istrahat sebagai mana yang disampaikan oleh operator MTs Darussa'adah diatas. Hal ini yang menyebabkan seringnya operator EMIS melakukan begadang atau lembur untuk input data, akan tetapi menurut Bapak Mustofa selaku operator EMIS mengtakan hal ini lebih baik daripada ketika kita menginput data pada jam-jam kerja tetapi pada akhirnya data tidak tersimpan pada EMIS.

Pada pengoprasiaannya, operator madrasah terlebih dahulu memperoleh pelatihan mengenai pelaksanaannya oleh Kementrian Agama setempat. Apabila terdapat pembaharuan pada fitur pada aplikasi, akan di informasikan kepada pihak madrasah untuk melakukan penyesuaian terhadap perubahan tersebut. Hsl ini diungkapkan oleh operator MTs Darussa'adah, sebagai berikut : ${ }^{10}$

"saat ada perubahan dan penambahan data pada EMIS, maka kita memperoleh pemberitahuan melalui surat edaran Kementrian Agama untuk melakukan rapat pertemuan di gedung aula Kentrian Agama, atau kadan juga di KKM induk. Selain surat edaran kita juga memperoleh pemberitahuan melalui grup whatsapp yang dibuat untuk memudahkan kami dan operator lain untuk sharing masalah yang berkaitan dengan EMIS."

Pengelolaan data EMIS yang dilakukan di MTs Darussa'adah tergolong baik, hal ini didukung oleh fasilitas yang tergolong memadahi yang diberikan oleh lembaga kepada operator, seperti penyediaan laptop dengan kapasitas yang mumpuni, paket data yang diberikan saat mengerjakan pendataan dirumah, dan lain-lain. Hanya saja kesulitan yang

\footnotetext{
${ }^{9}$ Opertor MTs Darussa'adah, Wawancara

${ }^{10}$ Opertor MTs Darussa'adah, Wawancara
} 
Leadership: Jurnal mahasiswa manajemen pendidikan Islam

ISSN (P): 2721-7108, ISSN (E): 2715-0399

Vol. 03 No. 01 bulan Desember 2021

sering dialami oleh operator EMIS di MTs Darussa'adah adalah terkait data siswa, dalam wawancara dengan Operator, baliau mengatakan terkait kesuliat yang dialami, yaitu $:^{11}$

"Kesulitan yang paling sering kami alami adalah saat pendataan siswa, hal ini dikarenaka MTs Darussa'adah merupakan lembaga dibawa naungan pesantren Darussa'adah Al Islamy yang mana $90 \%$ siswa berasal dari pesantren yang mereka berdomisili diluar desa Gubugklakah. Bahkan tidak sedikit yang mereka berasal dari luar Jawa Timur seperti Jawa Tengah, Jawa Barat, bakan Kalimantan. Sehingga proses pengumpulan kelengkapan data siswa sering terhambat, padahal data siswa yang diperlukan berupa ljaza, Sertifikat Hasil Ujian Nasional(SHUN),KK, dan juga KIP bagi yang mempunyai."

\section{Proses Pengolahan Data EMIS di MTs Darussa'adah Gubugklakah Kecamatan Poncokusumo}

Pengolahan data EMIS di MTs Darussa'adah memalui beberpa langkah yaitu pengumpulan data yang diperlukan, penginputan, penyimpanan, dan pengecekkan ulang.

\section{Proses Pengumpulan Data EMIS di MTs Darussa'adah Gubugklakah Kecamatan Poncokusumo}

Proses pengumpulan data dilakukan oleh operator mulai tahap pendataan awal, yaitu mulai pendataan lembaga, siswa, tenaga pendidik dan kependidikan. Akan tetapi pada proses ini operator madrasah lebih memfokuskan kepada kelengkapan data siswa, hal ini sebagai mana yang disampaikan diatas, bahwa keadaan siswa yang keseluruhannya siswa dari pesantren memerlukan waktu yang cukup lama untuk menunggu lengkapnya data. Sebagai mana yang dipaparkan oleh operator MTs Darussa'adah : $:^{12}$

"Pendataan EMIS dilakukan setiap awal ajaran baru, dan aka nada pembaruan tiap semester. Pada pendataan awal kami lebih focus kepada pendataan siswa, dikarenakan sulitnya pengumpulan data. Mungkin untuk saat ini mulai tertolong dengan adanya Whatsaap, jadi kami memnghubungi orang tua siswa di grup kelas agar memfotokan data yang kami perlukan untu input, itupun masih banyak yang belum lengkap. Hal itulah yang membuat kami lebih focus kepada pendataan siswa, dengan minta bantuan kepada masing-masing wali kelas untuk terus memberi himbauan kepada semua siswa terkait pengumpulan berkas data."

Terkait data khususnya yang berhubungan dengan siswa baru, Operator MTs Darussa'adah menambahkan bahwa : $:^{13}$

"sebenarnya untuk data siswa baru, formulir yang kami berikan sudah sesuai untuk kelengkapan yang bisa langsung kami input pada halaman EMIS, akan tetapi banyak dari orang tua yang tidak melengkapi pengisian formulir, dan juga hampir semua siswa

\footnotetext{
${ }^{11}$ Opertor MTs Darussa'adah, Wawancara

12 Opertor MTs Darussa'adah, Wawancara

${ }^{13}$ Opertor MTs Darussa'adah, Wawancara
} 
Leadership: Jurnal mahasiswa manajemen pendidikan Islam

ISSN (P): 2721-7108, ISSN (E): 2715-0399

Vol. 03 No. 01 bulan Desember 2021

di MTs kami, saat mendaftar, jadi satu dengan pendaftaran pesantren sehingga kelengkapan data juga kurang."

Sedangkan, untuk data yang lain seperti data lembaga, data sarpras, guru dan tenaga kependidikan, proses pengumpulan datanya tidak terlalu sulit hal ini dikarenakan data lembaga merupakan data sekolah yang keseluruhannya sudah tersedia di pengarsipan tata usaha

\section{Proses Penginputan Data EMIS di MTs Darussa'adah Gubugklakah Kecamatan Poncokusumo}

Setelah semua data terkumpul, operator Emis menginput data pada halaman Emis. Khusus untuk siswa, operator menginput melalui data dari formulir yang di isi oleh perserta didik, data tersebut diperoleh dari masing-masing walikelas yang membantu mendata pada tiap-tiap siswa di rombelnya masing-masing.

Tahap awal dari penginputan data siswa, menggunakan format excel yang diperoleh dari daskbord EMIS yang diisi kemudian diupload sebagaimana yahng dikatakan oleh operator madrasah :

"Untuk data peserta didik EMIS menyediakan form berbentuk excel. Form tersebut diisi kemudian diupload, data yang wajib diisi adalah NISN, NSM,NIK siswa, tempat tangal lahir siswa, asal sekolah, alamat, NPSN sekolah asal. Setelah diupload, kita menunggu data untuk di approve pusat hingga data siswa tersebut muncul di EMIS kita."

Tahap berikutnya setelah data sudah disetujui oleh EMIS pusat, operator akan melengkapi identitas didalamnya, seperti alamat domisili siswa, identitas dan alamat tempat tinggal orang tua, mengisi kolom kebutuhan khusus, data kelulusan, dan juga jenjang sebelumnya.

Sebagaimana pada penginputan data siswa, data kelengkapan lembaga juga harus dilengkapi. Hal ini meliputi identitas madrasah, kurikulum yang digunakan, pelaksanan kegiatan blajar dan mengajar. Data sarpras meliputi keadaan dan fasilitas sarana dan prasarana yang dimiliki, secara terperinci data sarpras yang di input diantaranya jumlah ruang kelas, jumlah kamar mandi, keberadaan tempat ibadah, luas masing-masing ruang, jumlah fasilitas lab yang dimiliki, dan masih banyak lagi.

\section{Proses Penyimpanan Data EMIS di MTs Darussa'adah Gubugklakah Kecamatan Poncokusumo}

Data yang telah diinputkan pada akhirnya adalah proses penyimpanan data, pada menu EMIS adalah proses konfirmasi yang menandakan bahwa data yang diinput adalah benar-benar sesuai dengan keadaan lembaga terkait. Pada proses penimpanan data EMIS, kendala yang sering dihadapi adalah lamanya proses penyimpanan, bahkan gagalnya data tersimpan yang disebabkan oleh server yang sering error. Hal ini seperti yang dijelaskan oleh operator MTs Darussa'adah bahwa : ${ }^{14}$

${ }^{14}$ Opertor MTs Darussa'adah, Wawancara 
"Apabila penyimpanan data dilakukan pada jam sibuk terkadang menyebabkan proses penyimpanan yang sangat lama dan seringkali data gagal di simpan, sehingga kita harus input ulang dari awal."

Eror dalam proses penyimpanan data EMIS tentunya menjadi hambatan paling besar bagi tiap operator, mengingat EMIS merupakan data utama pada setiap lembaga madrasah. $\mathrm{Hal}$ inilah yang menjadikan banyak dari kalangan operator yang lebih memilih untuk mengerjakan EMIS dijam ketika server sedang tidak sibuk sbagaimana yang telah dijelaskan oleh operator di MTs Darussa'adah. Kendala lain yang sering dihadapi operator adalah terkait akses internet. EMIS merupakan aplikasi online, sehingga membutuhkan koneksi internet yang benar-benar setabilagar proses penginputan dan penyimpanan data berjalan dengan lancar.

\section{Penelusuran Data EMIS di MTs Darussa'adah Gubugklakah Kecamatan Poncokusumo}

Jika semua data sudah tersimpan dan sudah masuk dalam EMIS, maka operator EMIS dapat melakukan penelusuran terhadap data dan informasi yang dibutuhka seperti pada menu kelembagaan kita bisa mengetahui tentang profil lembaga, rekap data guru dan tenaga kependidikan, rekap jumlah siswa, proses kegiatan belajar dan mengajar, bahkan keuangan dan bantuan yang diterima oleh sekolah.

Menu sarana dan prasarana, proses penelusuran bisa memperoleh informasi terkait keadaan lembaga, jumlah rombel, bahkan fasilitas yang dimiliki oleh madrasah. Hal ini bertujuan untuk menjaring sekolah-sekolah yang layak mendapat bantuan oleh pusat. Sebab, EMIS pusat dapat mengkroscek keadaan lembaga masing-masing sesuain dengan yang di inputkan oleh operator EMIS masing-masing madrasah

Menu kesiswaan, pada dasarnya menu keiswaan merupakan menu yang paling fital dalam emis, sebab melalui menu siswa ini dijadikan acuan oleh pemerintah untuk memberikan bantuan Dana BOS yaitu sesuai dengan jumlah siswa yang diinputkan dil EMIS. Dari menu siswa ini juga kita bisa memperoleh informasi terkait keadaan siswa, mulai dari identitas lengkap, tempat tinggal, identitas orang tua, siswa dengan kebutuhan khusus, data siswa yang layak menerima bantuan atau PIP, hingga informasi tentan sekolah siswa jenjang sebelumnya termasuk nilai ujian akhir. Kesemuanya dapat kita peroleh dari EMIS.

Menu guru dan tenga kependidikan atau GTK, menu ini menyajikan penelusuran lengkap terkait data guru dan tenaga kependidikan, mulai dari identitas lengkap, hingga riwayat pendidikan yang pernah ditempuh.

\section{Dampak Penggunnan EMIS Dalam Pengelolaan Data di MTs Darussa'adah Gubugklakah Kecamatan Poncokusumo}

Penggunaan EMIS dalam pengelolaan data lembaga di MTs Darussa'adah memberikan manfaat tersendiri yang dirasakan oleh operator bahkan pihak madrasah, sebagai mana yang diungkapkan olh operator madrasah $:^{15}$

"Pada dasarnya aplikasi EMIS memberikan kita kemudahan dalam mengakses informasi dan data terkait lembaga pendidikan, hanya saja masalah utama dari kesemua itu adalah EMIS adalah aplikasi berbasis online sehingga kita memerlukan

${ }^{15}$ Opertor MTs Darussa'adah, Wawancara 
akses data yang stabil dan juga seringnya system yang trobel. Akan tetapi untuk ke efisienan tentu lebih efisen EMIS daripada data ofline dikarenakan jika data itu offline kita masih harus ke kantor untuk mendapatkan data dan informasi yang kita perlukan, sedangkan dengan EMIS kita bisa mengakses dimanapun bahkan melalui handphone, yang penting kuncinya terletak pada jaringan yang harus stabil, dan server pusat yang tidak bermasalah.selain itu data lebih aman jika berbasis online."

Kemanan data memang sangat penting, hal ini untuk menjaga kualitas informasi yang ada pada lembaga pendidikan. Itulah mengapa dalam prosesnya EMIS memerlukan username dan password sehingga dapat membatasi siapa saja yang bisa mengaksesnya. Pada umumnya hanya operator dan kepala madrasah yang adat mengakses EMIS.

\section{Faktor Pendukung dan Penghambat Penerapan EMIS}

Melalui berbagai penjelasan dan wawancara dengan operator EMIS di MTs Darussa'adah secara umum terdapat faktor pendukung dan faktor penghambat dalam penerapan EMIS disemua lembaga, diantaranya :

\section{Faktor Pendukung :}

a. Peran kepala madrasah

Peran pemimpin dalam hal ini kepala madrasah sangat berkontribusi penting dalam penerapan EMIS. Sehingga, diharuskan kepala madrasah berkoordinasi dengan baik kepada tiap-tiap unit kerja. Sebab sebagai mana yang kita ketauhi banyak kendala yang dihadapi oleh operator madrasah. Disinilah peran kepala madrasah harus mampu mengambil kebijakan yang bertujuan untuk membantu penerapan EMIS di tiap-tiap lembaga. Misalnya, dengan mengalokasikan dana khusus untuk operator EMIS. Apabila ada hubungan yang baik antara kepala madrasah dan operator tentu EMIS akan menjadi lebih mudah dalam penerapannya.

b. Pemahaman terkait EMIS

EMIS sebagai pusat data dan informasi sekolah diharapkan mampu menjadi pedoman tiap lembaga. Olehkarena itu, diperlukan kevalidan data yang diinput didalamnya agar tidak salah dalam menentukan sasaran yang akan dicapai.itulah mengapa operator harus menguasai sedikit banyak terkait seluk beluk didalam EMIS sebab, operator memiliki kontribusi besar dalam penerapan EMIS ditiap lembaga.

\section{Faktor Penghambat :}

\section{a. Anggaran}

Anggaran merupakan hal yang sangat vital, sebab anggaran merupaka reward setiap pekerjaan yang dilakukan. Lebih-lebih untuk para operator, mengingat EMIS bukanlah lah yang muda, banyak kendala yang ditemukan, dan juga hampir seluruh operator mengerjakan dijam-jam istirahat atau jam malam, sehingga seyogyanya bagi lembaga harus memberikan anggaran untuk tugas operator sebagai reward atas kinejanya. Seperti uang lembur dan paket data internet.

b. Kualitas Operator

Sebagaimana faktor anggaran, kualitas operator juga bagian terpenting, sebab operator merupakan pelaku yang berkecimpung langsung dengan EMIS. Kulaitas operator harus mendukung penuh, sehingga segala hal yang ada didalam EMIS bisa teratasi dengan baik. 
Leadership: Jurnal mahasiswa manajemen pendidikan Islam

ISSN (P): 2721-7108, ISSN (E): 2715-0399

Vol. 03 No. 01 bulan Desember 2021

\section{KESIMPULAN DAN SARAN}

\section{Kesimpulan}

Berdasarkan data-data yang terkumpul dari penelitian "Implementasi Education Management Information System Dalam Mengelolah Data Di MTs Darussa'adah Gubugklakah Keacamatan Poncokusumo" yang telah dijelaskan pada bagian-bagian sebelumnya, peneliti dapat menarik kesimpulan bahwa :

1. Pengelolaan Data Lembaga di MTs Darussa'adah Gubugklakah Kecamatan Poncokusumo berbasis Sistem Informasi Manajemen yang dilakukan secara online melalui aplikasi EMIS yang merupakan aplikasi pendataan lembaga oleh Kementrian Agama, yang digunakan untuk mengetahui informasi dan data setiap lembaga dibawah naungannya secara riil.

2. Langkah awal dalam menggunakan EMIS adalah dengan mendaftarkan akun lembaga ke EMIS SDM, setelah di setujui dan aktif, maka secara otomatis akun lembaga akan terdaftar pada halaman EMIS yang nantinya akan digunakan sebagai username saat akan login ke halaman EMIS.

3. Didalam EMIS mencakup data kelembagaan dengan bagian didalamnya meliputi menu profil lembaga, rekap guru dan tenaga kependidikan, rekap siswa, proses kegiatan belajar dan mengajar, keuangan dan bantuan. Menu sarana prasarana yang didalamnya meliput secara detail sarana dan prasarana yang dimiliki oleh lembaga terkait. Menu kesiswaan, didalamnya meliputi menu siswa aktif, ringkasan siswa perrombel, lulusan siswa, mutasi masuk dan keluar, data alumni, siswa non aktif, dan siswa yang terdeteksi ganda. Menu guru dan tenaga kependidikan, didalamnya mencakup informasi lengkap data guru dan tenaga kependidikan. Menu template, menu konfirmasi, dan terakhir menu log out.

4. Proses pengolahan data lembaga di MTs Darussa'adah melalui empat langkah utama yaitu proses pengumpulan data, penginputan, penyimpanan informasi, dan penelusuran kembali untuk mencari informasi dan data yang dibutukan sewaktu-waktu.

5. EMIS yang diterapkan di MTs Darussa'adah dalam pengelolaan data lembaga memberikan dampak yang baik bagi yaitu berupa kemudahan dalam penyimpanan data yang ada, sehingga ketika data diperlukan lembaga akan langsung mencari dengan login ke halaman EMIS, dikarenakan EMIS aplikasi online yang bisa diakses dimanapun dan kapanpun.

6. Kendala dalam mengoprasikan EMIS adalah seringnya trobel pada server pusat sehingga sulit untuk login kedalamnya, hal ini yang menyebabkan operator EMIS kebanyakan menginput data ketika di jam-jam instirahat seperti jam 22 malam hingga jam 3 pagi. Kendala lain ya g ditemukan adalah saat proses penyimpanan data harus menggunakan jaringan internet yang stabul, dikarenakan jika internet tidak setabil maka data akan gagal tersimpan dan operator harus mengulang lagi untuk input data.

7. Fakor pendukung diterapkannya EMIS di MTs Darussa'adah adalah yang pertama Kepala Madrasah yang berperan penting dalam memberikan kontribusi dan membantu mengambil kebijakan-kebijakan untuk membantu operator madrasah dalam proses penginputan data EMIS. Kedua pemahaman terhadap penerapan aplikasi EMIS.

8. Faktor penghambat diterapkannya EMIS di MTs Darussa'adah adalah, pertama faktor anggaran yang menjadi penunjang bagi operator dalam pengoprasian EMIS sebagai reward. Yang kedua kualitas operator, bahwa selain anggaran penghambat EMIS adalah kualitas operator, yaitu sejauh mana operator menguasai seluk beluk aplikasi EMIS yang diterapkan dilembaga terkait. 
Leadership: Jurnal mahasiswa manajemen pendidikan Islam

ISSN (P): 2721-7108, ISSN (E): 2715-0399

Vol. 03 No. 01 bulan Desember 2021

\section{SARAN}

Adapun saran-saran yang dapat diberikan sehubungan dengan dilakukannya penelitian dilembaga MTs darussa'adah Gubugklakah Kecamatan Poncokusumo terkait Implementasi Education Managemen Information System (EMIS) dalam Mengelolah Data Lembaga, antara lain:

1. Aplikasi EMIS merupakan aplikasi berbasis online, sehingga lembaga pendidikan harus memfasilitasi operator EMIS seperti penyediaan komputer atau laptop yang mendukung kinerja operator, dan juga paket data yang digunakan untuk input EMIS dikarenakan seringnya operator mengerjakan EMIS dijam-jam istirahat seperti jam 22 malam hingga jam 3 pagi. Lembaga pendidikan harus memperhatikan reward yang diberikan kepada operator sebagai apresisasi terkait pengerjaan EMIS yang tergolong rumit.

2. Kepala Madrasah harus memberikan kebijakan-kebijakan yang membantu proses lancarnya pengelolaan data EMIS, seperti memberdayakan wali kelas untuk membantu pengumpulan data siswa yang diprlukan oleh operator EMIS dalam pengelolaan data.

3. Perlunya peningkatan daya server sehingga pengoprasian EMIS lebih stabil. Sebab kondisi server yang sering sibuk sangat memperlambat kinerja operator dalam memproses, mengupdate, dan menyimpan data.

\section{DAFTAR PUSTAKA}

Arfan Selvia, Yumni Muhammad, T Yusuf Muh. 2019. Penerapan Sistem Informasi Manajemen dalam Pengeolahan Data Peserta Didik Di MI Nasrul Haq.

Aziz Fauzi. 2014. Pengambilan Kebijakan Berbasis Education Manajenen Inforation System (EMIS).

Sina Rasdiana, Fatmawati, Masyhar Abdul. 2020. Penerapan Education Management Information System(EMIS) Di Lembaga Pendidikan Keagamaan dan Pondok Pesantren Pada Kantor Kementrian Agama Kota

Syarip Irawan Dodi, Rosyidin. 2003. System Manajemen Data dan Informasi Pendidikan di Lingkungan Diretorat Jenderal Kelembagaan Agama Islam. Jakarta : Departemen Agama RI 